\title{
Characterization of Bark-Midrib Fibers using Chemical Treatment Variations as Reinforcement in Bark-Midrib Fiber Composites
}

\section{Oliever Andrea Parusha', Muhammad Nurhidayatur Rozikin ${ }^{2}$, Andromeda Dwi Laksono ${ }^{3}$, Gusti $^{1}$ Umindya Tajalla ${ }^{4}$, Nabilla Amalia Putri ${ }^{5}$, Fitriana Maharani Fatchur Rochim ${ }^{6}$}

\footnotetext{
${ }^{1}$ Material and Metallurgical Engineering, Kalimantan Institute of Technology, Balikpapan. Email: 06151033@student.itk.ac.id

${ }^{2}$ Material and Metallurgical Engineering, Kalimantan Institute of Technology, Balikpapan. Email: 06171050@student.itk.ac.id

${ }^{3}$ Material and Metallurgical Engineering, Kalimantan Institute of Technology, Balikpapan. Email: andromeda@lecturer.itk.ac.id

${ }^{4}$ Material and Metallurgical Engineering, Kalimantan Institute of Technology, Balikpapan. Email: gusti.unt@lecturer.itk.ac.id

${ }^{5}$ Material and Metallurgical Engineering, Kalimantan Institute of Technology, Balikpapan. Email: 06171053@student.itk.ac.id

${ }^{6}$ Material and Metallurgical Engineering, Kalimantan Institute of Technology, Balikpapan. Email: 06171033@student.itk.ac.id
}

\begin{abstract}
Bark midrib are not fully utilized. Utilize the characterization of the fiber and process it into polymer composites with natural fiber reinforcement. The study was conducted using a variety of chemical treatments in the form of bark midribs without treatment, delignification treatment that is immersion using $\mathrm{NaOH}$ media concentration of $1 \%, 5 \%, 10 \%$ with 3 hours immersion time and bleaching treatment using $\mathrm{H}_{2} \mathrm{O}_{2}$ media $2 \%$ concentration with immersion time 30, 60 and 90 minutes. In obtaining suitable properties, tensile tests, impact tests, Scanning Electron Microscopy (SEM) images, and Fourier-Transform Infra-Red (FTIR) tests are performed. Optimal delignification treatment at $5 \% \mathrm{NaOH}$ concentration with a tensile test value of $25.47 \mathrm{MPa}$ (increasing $76.86 \%$ ) and an impact test value of $11.95 \mathrm{~kJ} / \mathrm{m}^{2}$ (increasing $11.45 \%$ ). The optimal bleaching treatment at 90 minutes immersion with a tensile test value of $35.09 \mathrm{MPa}$ (increased $36.36 \%$ ) and impact test value of $13.77 \mathrm{~kJ} / \mathrm{m}^{2}$ (increased $15.22 \%$ ). The results of SEM images show that the bark midrib fiber composite without treatment has a lousy interface, delignification treatment with a reasonable good interface, and bleaching treatment with an excellent interface. FTIR test results showed that the bark midrib fiber composite without treatment had a cellulose component but hemicellulose and lignin levels still dominated. Based on the results of the study, bark midrib fiber with delignification chemical treatment using $5 \% \mathrm{NaOH}$ for 3 hours followed by bleaching treatment using $2 \% \mathrm{H}_{2} \mathrm{O}_{2}$ for 90 minutes is the treatment with the best results and then applied to a natural fiber composite product.
\end{abstract}

Keywords: Composite, bark-midrib fiber, epoxy, SEM

\begin{abstract}
Abstrak
Pelepah salak tidak sepenuhnya dimanfaatkan. Maka dari itu perlu dilakukan karakterisasi serat dan proses menjadi komposit polimer dengan penguat serat alami. Penelitian ini dilakukan dengan menggunakan berbagai perlakuan kimia dalam bentuk pelepah salak tanpa perlakuan, perlakuan delignifikasi yaitu perendaman menggunakan konsentrasi media $\mathrm{NaOH}$ 1\%, 5\%, 10\% dengan waktu perendaman 3 jam dan perlakuan pemutihan menggunakan media $\mathrm{H}_{2} \mathrm{O}_{2} 2 \%$ konsentrasi dengan waktu perendaman 30, 60 dan 90 menit. Dalam memperoleh properti dilakukan uji tarik, uji impak, pengamatan Scanning Electron Microscopy (SEM), dan Fourier-Transform Infra-Red (FTIR). Perlakuan delignifikasi optimal terjadi pada konsentrasi NaOH 5\% dengan nilai uji tarik 25,47 MPa (meningkat 76,86\%) dan nilai uji impak 11,95 kJ/m² (meningkat 11,45\%). Hasil proses pemutihan yang optimal pada perendaman 90 menit dengan nilai uji tarik 35,09 MPa (meningkat $36,36 \%$ ) dan nilai uji impak 13,77 kJ/m (meningkat 15,22\%). Hasil gambar SEM menunjukkan bahwa komposit serat pelepah salak tanpa perlakuan memiliki antarmuka yang buruk, perlakuan delignifikasi memilki
\end{abstract}




\section{Characterization of Bark-Midrib Fibers using Chemical Treatment Variations as \\ Reinforcement in Bark-Midrib Fiber Composites}

antarmuka yang baik, dan perlakuan pemutihan memiliki antarmuka yang sangat baik. Hasil uji FTIR menunjukkan bahwa komposit serat pelepah salak tanpa perlakuan memiliki komponen selulosa tetapi kadar hemiselulosa dan lignin masih mendominasi. Berdasarkan hasil penelitian, serat pelepah salak dengan perlakuan kimia delignifikasi menggunakan 5\% NaOH selama 3 jam diikuti dengan perlakuan pemutihan menggunakan $2 \% \mathrm{H}_{2} \mathrm{O}_{2}$ selama 90 menit adalah perlakuan dengan hasil terbaik dan kemudian dapat diterapkan pada produk komposit serat alami.

Kata Kunci: Komposit, serat pelepah salak, epoksi, SEM

\section{Introduction}

In the application, the composite polymer with reinforcing fibers nature has the potential to be utilized in a variety of sectors, one of which is a component of a vehicle. Especially part bumper cars are a component of the first that protects the car from the collision on the vehicle in the condition of load impact low as at the time the car was parked or collisions on objects other. The materials that compose components of bumper cars require properties of the mechanical form of modulus of elasticity and resistance to load shock that high.

According to the Ministry of Agriculture of the Republic of Indonesia 2013, the production of bark in Indonesia in the years 2010, 2011, and 2012 respectively reached 749 876, 1,082,115, and 1,035,406 tons. However, at this time, the use of bark plants is very focused on the preparation of fruit and seeds only. For the sake of reducing waste due to the production of fruit bark as well as to add value crops barking, then made use of fiber midrib bark in the manufacture of composite polymer with reinforcing fibers nature. In the area of Balikpapan itself, there is plantations bark belonging to residents who are located at KM. 23. This plantation has the potential to be able to initiate the use of bark midrib fiber as a composite material.

Fiber to the base of the stem of the plant bark has a content of cellulose reached $42.54 \%$, and hemicellulose reached $34.35 \%$ and lignin up to $28.01 \%$. Levels of cellulose can be used more efficiently by using treatment chemicals, namely the treatment of delignification and bleaching. It has been confirmed that the cellulose is a component of the fiber of nature with the nature of the mechanical top, which reached 750-1080 MPa (Raharjo, 2016).

In the study, the specimens will use resin epoxy as a matrix polymer and fiber midrib bark as an amplifier with a ratio of the fraction of the volume based on the results of research Fadli (2017) who reached the conditions optimal to the value of $40 \%$ fiber midrib bark and $60 \%$ resin. The variables in this study are chemical treatments where there are 3 variables namely fiber without treatment, fiber with delignification treatment using $1 \% \mathrm{NaOH}$ solution, $5 \%$ and $10 \%$ temperature $30^{\circ} \mathrm{C}$ for 3 hours, and fiber with delignification treatment using $\mathrm{NaOH}$ solution at optimal temperature conditions $30^{\circ} \mathrm{C}$ for 3 hours followed by a bleaching process with $\mathrm{H}_{2} \mathrm{O}_{2} 2 \%$ for 30,60 and 90 minutes. Tests were conducted on specimens are testing against the nature of the mechanical with the testing of tensile, testing the resilience of impact (ASTM D-6110) as well as the analysis of the cluster functionality chemistry by using test FTIR and the analysis of the morphology of the interface between the matrix polymer with fiber nature by using SEM.

The purpose of this study is to find out the effect on the mechanical properties of $\mathrm{NaOH}$ levels $(1,5$, and $10 \%)$ in the delignification process, to find out the influence of the length of time $(30,60$, and 90 minutes) with the bleaching process, and to find out the influence of variation of chemical treatments $\left(\mathrm{H}_{2} \mathrm{O}_{2}\right.$ and $\left.\mathrm{NaOH}\right)$ carried out on bark midribs of the $60 \%$ epoxy matrix polymer composite specimens with $40 \%$ bark midrib reinforcement fibers.

\section{Materials and Method}

Broadly speaking, the research "Characterization of Bark- Midrib Fibers Using Chemical Treatment Variations as Reinforcement in Bark-Midrib Fiber Composites" was carried out in several stages, 


\section{Characterization of Bark-Midrib Fibers using Chemical Treatment Variations as Reinforcement in Bark-Midrib Fiber Composites}

namely the preparation of experimental material, the stage of variation of fiber treatment, the stage of making composites, the stage of testing, and the stage testing data processing.

In the preparation stage of the experimental material, the extraction of fiber from the bark of plants by immersing the midribs is cut, then pulling the bark of fiber one by one and then brushed cleanly to remove the remaining cambium in the fiber and continued with the process of drying the fiber using an oven with a rising temperature until $80^{\circ} \mathrm{C}$ for approximately 1.5 hours to reduce the water content in the fiber.

At the variation stage of fiber treatment, three types of variables were carried out, namely P0 as no treatment, P1 as delignification, and P2 as delignification followed by bleaching. Process without direct

treatment using dried bark midrib fiber for further processing, then the process with delignification is done by making $\mathrm{NaOH}$ solution with 3 variables, $\mathrm{NaOH} 1 \%$ (2 gr in $200 \mathrm{ml}), 5 \%$ (10 gr in $200 \mathrm{ml}$ ) and $10 \%$ ( $20 \mathrm{gr}$ in $200 \mathrm{ml}$ ), then soak the bark fiber in a solution that has been made at $30^{\circ} \mathrm{C}$ for 3 hours, and rinse the bark fiber with distilled water to a neutral $\mathrm{pH}$. Moreover, with the process with delignification followed by bleaching is done the same as the previous delignification process. However, after rinsing with distilled water to neutral $\mathrm{pH}$, the fiber with the optimum delignification treatment value is immersed again given the first treatment making a $2 \% \mathrm{H}_{2} \mathrm{O}_{2}$ solution $(10 \mathrm{ml}$ in 240 $\mathrm{ml}$ ), then soaked the optimum delignification treatment fiber in a $2 \% \mathrm{H}_{2} \mathrm{O}_{2}$ solution at a temperature of $80^{\circ} \mathrm{C}$ held for 30, 60 and 90 minutes, and finally rinsed the barking fiber using distilled water to neutral $\mathrm{pH}$. After each treatment, the fibers are then dried again using the oven using a temperature of $80^{\circ} \mathrm{C}$ and stored in a vessel together with silica gel to reduce the moisture of the fiber. After being treated, FTIR testing of the fiber is then carried out as a reference to the efficiency of the chemical treatment by testing the content of each fiber. Each variation was being tested by one specimen for FTIR characterization.

At the composite manufacturing stage, the composite manufacturing process is carried out by mixing the epoxy resin matrix with bark midrib fiber using a volume fraction ratio of $40 \%$ fiber to $60 \%$ epoxy resin matrix according to the calculation of the mole fraction that has been done, then mixed with a uniform fiber orientation at an angle of $0^{\circ}$. A test sample is made by following the provisions of the ASTM test standard.

During the testing phase, mechanical properties were tested on three samples each variation in the form of tensile testing and impact resistance testing according to ASTM D-6110 standard. Meanwhile, an interface morphology analysis was carried out using SEM on the optimal condition specimens of each treatment to observe the morphology and interactions between the epoxy matrix on the surface of the midrib fiber bark. Each variation was being tested by one specimen for SEM characterization.

At the stage of processing the test data, interpretation of the impact test data is used to find the value of the resistance of the composite of barking fiber fiber in receiving the impact load, then data from the tensile test process is used to calculate the tensile strength and modulus of elasticity of the bark fiber fiber composite composite, and the interpretation of morphological analysis results interface to determine the optimal chemical treatment for the utilization of bark midrib fiber as a renewable natural fiber composite.

\section{Results and Discussion}

\subsection{Delignification Process on Bark Midrib Fiber}

Delignification process or alkalization on bark midrib fiber performed using $\mathrm{NaOH}$ solution with three variables, which is $\mathrm{NaOH} 1 \%, 5 \%$, and $10 \%$. The following bellow is Table 1 of variations in delignification treatment.

Table 1: Variations in delignification treatment of bark midrib fiber

\begin{tabular}{llll}
\hline Treatment & Mass $(\mathrm{g})$ & Temp $\left({ }^{\circ} \mathrm{C}\right)$ & Time (hours) \\
\hline
\end{tabular}


Characterization of Bark-Midrib Fibers using Chemical Treatment Variations as Reinforcement in Bark-Midrib Fiber Composites

\begin{tabular}{cccccc}
\hline \multicolumn{1}{c}{ NaOH } & Water & Fiber & & \\
\hline $1 \%$ & 2 & 200 & 8 & 30 & 3 \\
$5 \%$ & 10 & 200 & 8 & 30 & 3 \\
$10 \%$ & 20 & 200 & 8 & 30 & 3 \\
\hline
\end{tabular}

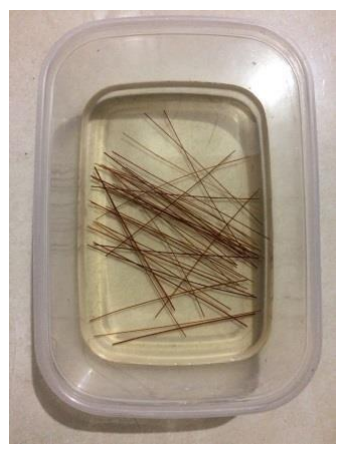

(a)

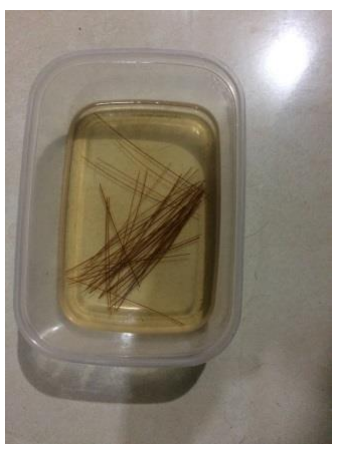

(b)

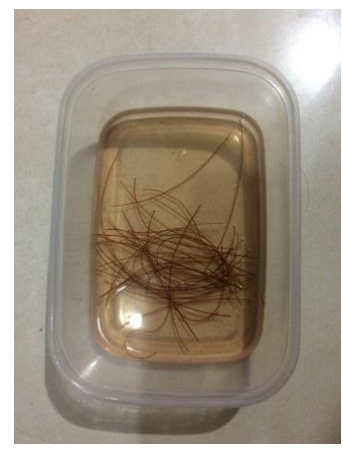

(c)

Figure 1: Delignification Treatment after Being Submersion in $\mathrm{NaOH}$ Solutions (a) $\mathrm{NaOH} 1 \%$ (b) $\mathrm{NaOH} 5 \%$ (c) $\mathrm{NaOH} 10 \%$

Figure 1 shows that the longer the treatment, the $\mathrm{NaOH}$ solution becomes darker. This shows that the phenolic salt dissolved in $\mathrm{NaOH}$ from a more concentrated black leachate along with the increasing percentage of the concentration of $\mathrm{NaOH}$ solution used. Lignin and hemicellulose are hydrophobic, the more the substance is dissolved, it will increase the bond between the matrix and the fiber, resulting in a stronger composite.

\subsection{Bleaching Process on Bark Midribs Fiber}

The bleaching process on bark midribs fiber is carried out after the optimization from delignification treatment. The bleaching process is carried out from the result of a 5\% delignification process followed by the immersion process using a $2 \% \mathrm{H}_{2} \mathrm{O}_{2}$ solution with three variables, 30 minutes, 60 minutes, and 90 minutes. The following bellow is Table 2 of variations in bleaching treatment and the result of bleaching treatment.

Table 2: Variations of bleaching treatment on bark midrib fiber

\begin{tabular}{|c|c|c|c|c|}
\hline \multirow{2}{*}{ Treatment } & \multicolumn{2}{|c|}{ Volume (ml) } & \multirow[t]{2}{*}{ Mass of fiber ( $g$ ) } & \multirow{2}{*}{ Temperature $\left({ }^{\circ} \mathrm{C}\right)$} \\
\hline & $\begin{array}{l}\mathrm{H}_{2} \mathrm{O}_{2} \\
50 \%\end{array}$ & Water & & \\
\hline $\begin{array}{c}30 \\
\text { minutes }\end{array}$ & 10 & 240 & 8 & 80 \\
\hline $\begin{array}{c}60 \\
\text { minutes }\end{array}$ & 10 & 240 & 8 & 80 \\
\hline $\begin{array}{c}90 \\
\text { minutes }\end{array}$ & 10 & 240 & 8 & 80 \\
\hline
\end{tabular}
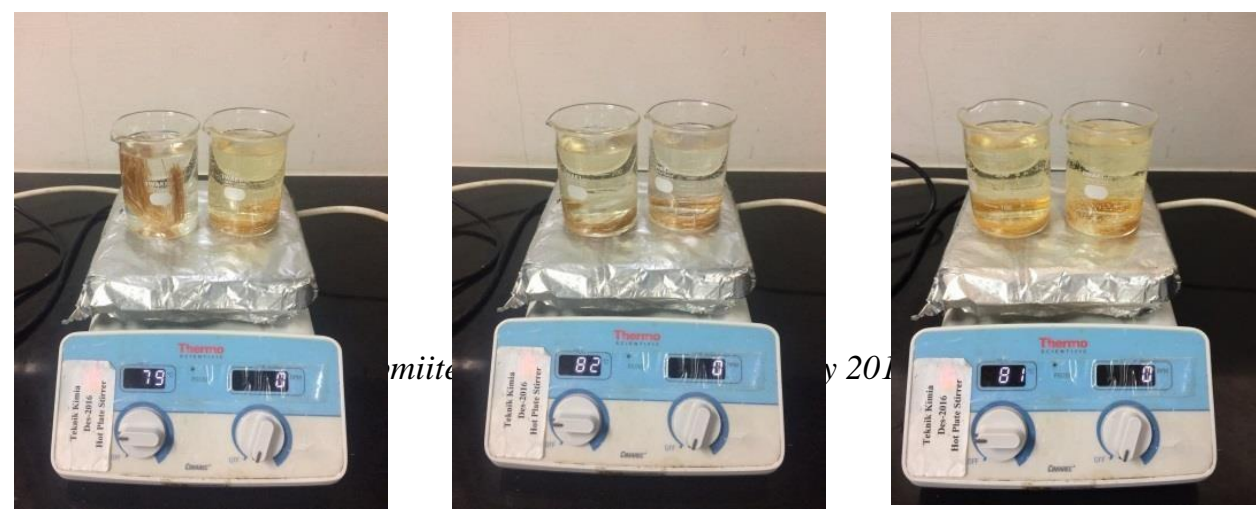
(a) (b)

(c) Minutes

Figure 2 shows that the longer the immersion time, bleaching treatment will produce a brighter fiber. It means the remaining lignin and impurities on fiber going to dissolve. With the disappearance of lignin and hemicellulose, cellulose will become the dominant material in the fiber thereby increasing the mechanical properties and crystallinity of the fiber.

\subsection{Tensile Strength on Bark Midrib Fiber Composite after Delignification and Bleaching Processes}

In this examination, tensile strength was carried out on bark midrib fiber composite with the following results.

Table 3: Tensile strength from bark midrib fiber composite

\begin{tabular}{c|c}
\hline Chemical Treatment & Average $\boldsymbol{\sigma}(\mathbf{M P a})$ \\
\hline Without treatment & 17.00 \\
\hline $\mathrm{NaOH} 1 \%$ & 22.77 \\
\hline $\mathrm{NaOH} 5 \%$ & 25.47 \\
\hline $\mathrm{NaOH} 10 \%$ & 23.15 \\
\hline $\mathrm{NaOH} 5 \%+\mathrm{H}_{2} \mathrm{O}_{2} 30$ minutes & 15.27 \\
\hline $\mathrm{NaOH} 5 \%+\mathrm{H}_{2} \mathrm{O}_{2} 60$ minutes & 29.98 \\
\hline $\mathrm{NaOH} 5 \%+\mathrm{H}_{2} \mathrm{O}_{2} 90$ minutes & 35.09 \\
\hline
\end{tabular}

From Table 3 shows that tensile strength from bark midrib fiber composite with delignification dan bleaching process has higher tensile strength rather than bark midrib fiber composite without treatment. In delignification process, tensile strength from $1 \% \mathrm{NaOH}$ with $22.77 \mathrm{MPa}$ to $25.47 \mathrm{MPa}$ from $5 \% \mathrm{NaOH}$. While the tensile strength decrease from $5 \% \mathrm{NaOH}$ with $25.47 \mathrm{Mpa}$ to $23.15 \mathrm{Mpa}$ from $10 \% \mathrm{NaOH}$ due to the influence of chemical degradation. The previous study confirmed that the optimal bending strength in the bending test was $65.63 \mathrm{MPa}$ in fiber composites with 5\% alkalization treatment. The alkalization treatment was used with $3 \%, 5 \%$, and $7 \%$. Hemicellulose, lignin, and cellulose will be dissolved thus the strength of natural fibers will decrease. It is possible that the increasing concentration of excessive alkali can remove some lignin from natural fibers which is the strength of composite natural fibers (Laksono et al, 2019).

Tensile strength on the bleaching process with $\mathrm{H}_{2} \mathrm{O}_{2}$ in 30 minutes is $15.27 \mathrm{MPa}$, then it increases to $29.98 \mathrm{Mpa}$ from the bleaching process in 60 minutes and increases again to $35.09 \mathrm{MPa}$ from the bleaching process in 90 minutes. This tensile strength with chemical treatment shows an increase in double the value of tensile strength without chemical treatment as shown in Figure 3.

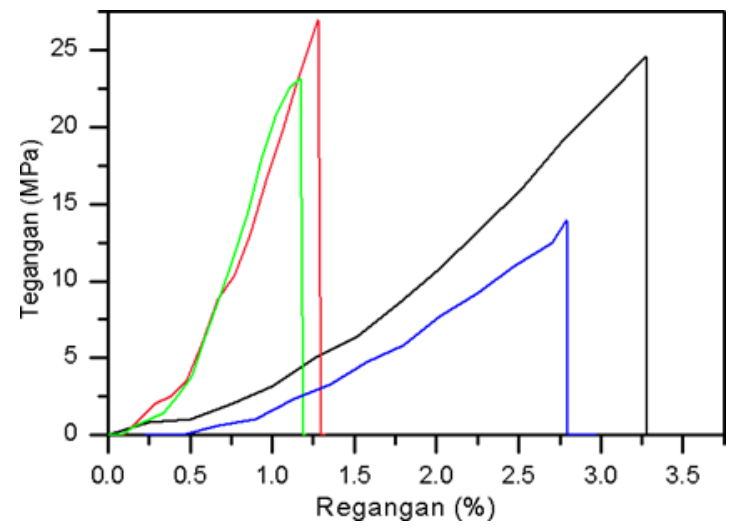

Figure 3: Strength and Strain Composite P0 \& P1 
Characterization of Bark-Midrib Fibers using Chemical Treatment Variations as

Reinforcement in Bark-Midrib Fiber Composites

\subsection{Impact Strength of Bark Midrib Fiber Composition After Delignification and Bleaching Process}

In this examination, impact strength was carried out on bark midrib fiber composite with the following results.

Table 4: Impact strength on bark midrib fiber composite

\begin{tabular}{c|c}
\hline Treatment & Impact Strength Average $\mathbf{( k J / \mathbf { m } ^ { 2 } )}$ \\
\hline Without treatment & 10.72 \\
\hline $\mathrm{NaOH} 1 \%$ & 10.71 \\
\hline $\mathrm{NaOH} 5 \%$ & 11.95 \\
\hline $\mathrm{NaOH} 10 \%$ & 6.46 \\
\hline $\mathrm{NaOH} 5 \%+\mathrm{H}_{2} \mathrm{O}_{2} 2 \% 30$ minutes & 11.46 \\
\hline $\mathrm{NaOH} 5 \%+\mathrm{H}_{2} \mathrm{O}_{2} 2 \% 60$ minutes & 10.21 \\
\hline $\mathrm{NaOH} 5 \%+\mathrm{H}_{2} \mathrm{O}_{2} 2 \% 90$ minutes & 13.77 \\
\hline
\end{tabular}

Table 4 shows, not all chemical treatment that has been done on fiber can increase impact strength on composite. from delignification treatment, impact strength on $5 \% \mathrm{NaOH}$ has higher impact strength rather than fiber without examination. In treatment $1 \%$ and $10 \%$, impact strength tends to decrease compared to fiber without examination. In bleaching treatment, impact strength increase in bleaching with immerse time 30 minutes and 90 minutes, on the other side, impact strength decrease in bleaching with immerse time 60 minutes as shown in Figure 4.

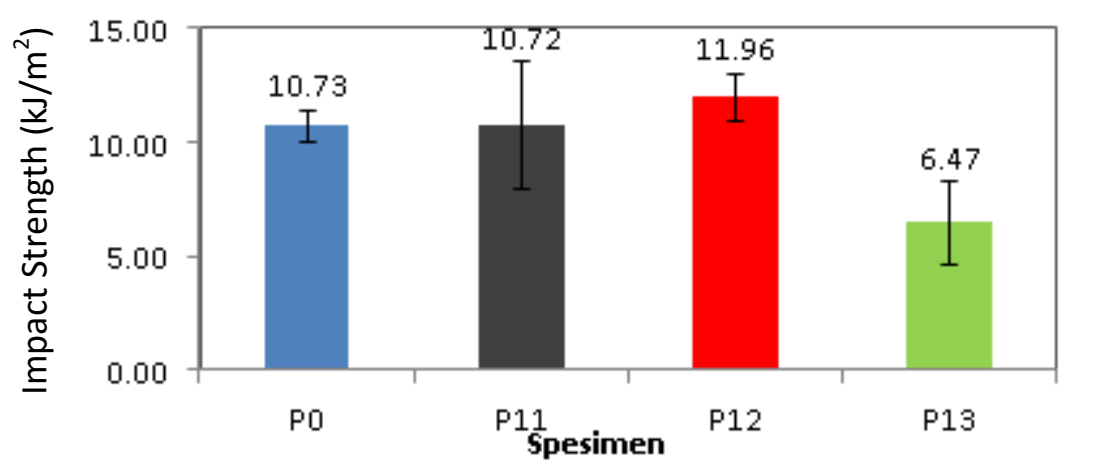

Figure 4: Impact Strength Composite P0 and P1

\subsection{Result of SEM Examination}

SEM (Scanning Electron Microscopy) was carried out to determine the interface between matrix and bio fiber. The following bellow is the result of SEM examination before and after treatment. 
Characterization of Bark-Midrib Fibers using Chemical Treatment Variations as Reinforcement in Bark-Midrib Fiber Composites

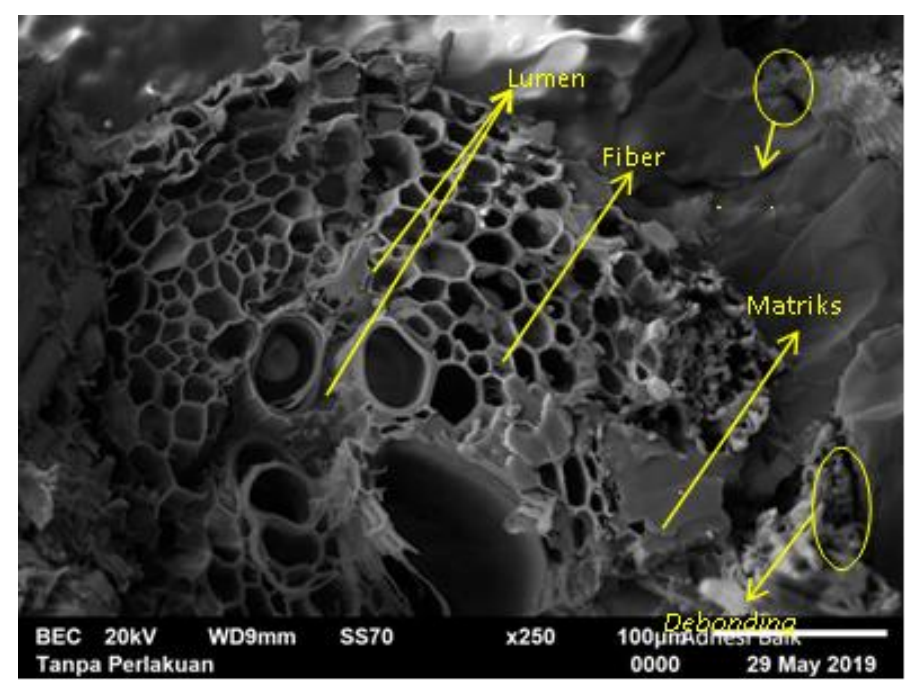

Figure 5: SEM Examination on Composite without Treatment

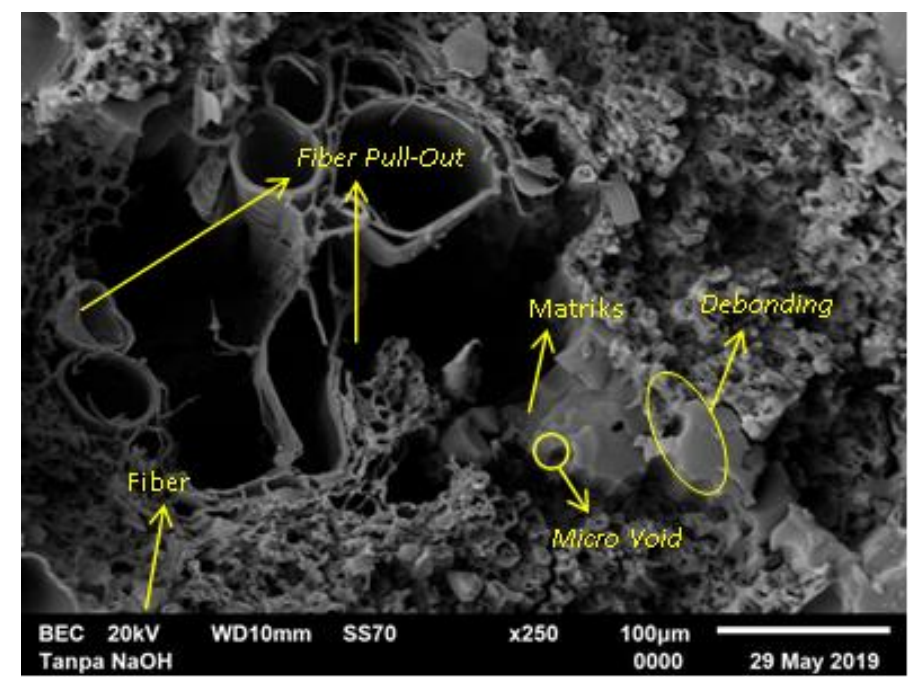

Figure 6: SEM Examination on Composite after Delignification Treatment

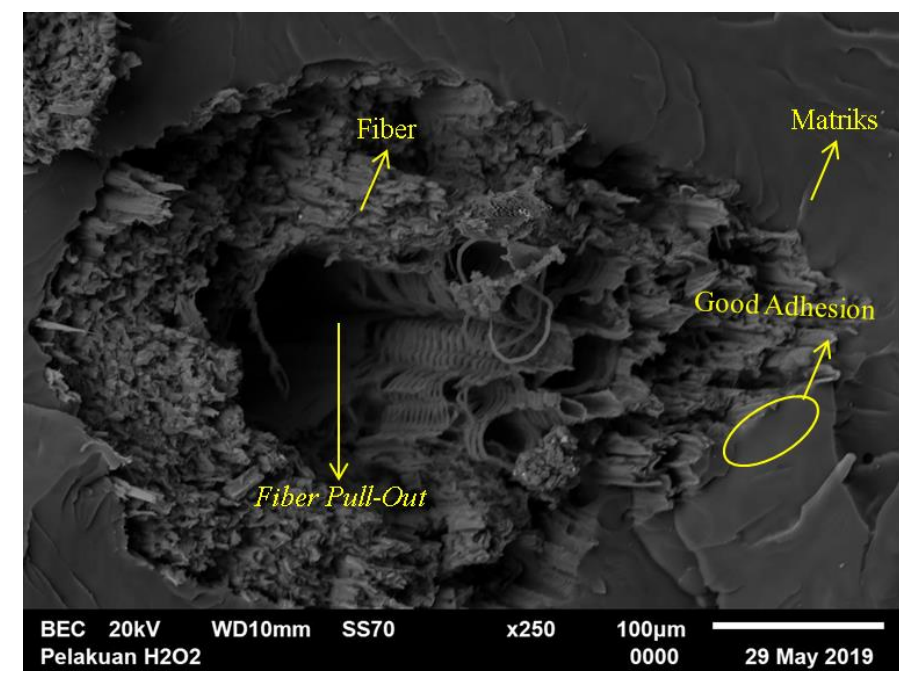

Figure 7: SEM Examination on Composite after Bleaching Treatment

Figure 5 shows there is an interfacial gap that determines fiber with a matrix, there is still no good adhesion strength. From the structure of the fibers in the Figure 5 also shows that there is still a lumen on the inside of the fiber that maintains the structure of the fiber so there are more voids in the fiber 


\section{Characterization of Bark-Midrib Fibers using Chemical Treatment Variations as Reinforcement in Bark-Midrib Fiber Composites}

and the shape of the cell wall is still intact and smooth, this is indicating the presence of lignin and hemicellulose in the fibers used.

From Figure 6, it is indicated that there is debonding between the matrix and the fiber, but there is also a fiber pull-out. The presence of fiber pull-out indirectly indicates that the interface between the matrix and the resin is better so that failure does not only occur at the interface of the matrix and filler but also occurs on the inside of the fiber. From the picture, there is also an indication of the presence of a micro void, which can initiate a failure on the composite. From the fiber structure in the figure, the lumen and cell walls have begun to degrade, causing the deformed fiber structure to reduce the presence of lignin, hemicellulose, and the number of voids in the fiber and increase the density value of the fibers.

From Figure 7, there is good adhesion between the matrix and the filler and there is no visible debonding, but there is a fiber pull-out. This indicates the interface between the fiber and the matrix is very good so that the failure does not occur on the interface but occurs on the inside of the fiber in the form fiber pull-out. Fiber pull out can indicate the bond between the fiber and the matrix is not strong enough, this certainly reduces the mechanical properties of the composite because the bond between the matrix and the fiber is weak (Laksono, et al. 2019). The structure of the fiber also does not show the presence of cell walls between microfibrils of the fiber, indicating that hemicellulose and lignin have been significantly reduced.

\subsection{Result of FTIR Examination}

FTIR (Fourier Transform Infra Red) tests were carried out to determine the characterization of chemical functional groups that occur in the sample used. FTIR was performed using a FTIR Spectrophotometer (Perkin-Elmer) with the $\mathrm{KBr}$ pellet method.

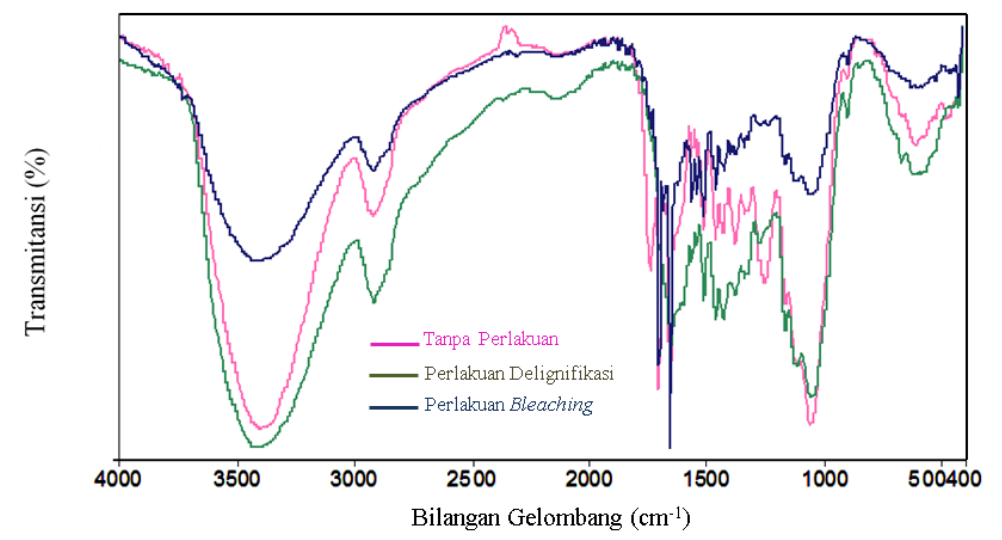

Figure 8: Comparison of FTIR Result of Bark Midrib Fiber

From Figure 8, the comparative efficiency of hemicellulose and lignin removal is identified by each treatment. Because the structure and binding are similar to cellulose, removal of hemicellulose and lignin can reduce the absorption intensity at wavenumbers around 3260-3280 (stretching OH), 2900 (stretching $\mathrm{CH}$ ), 1500 (stretching $\mathrm{C}=\mathrm{C}$ ), and $1040 \mathrm{~cm}-1$ (stretching) $\mathrm{CO}$ ).

It can be seen that in the bark midrib treatment fiber delignification when compared to the bark midrib fiber treatment without having the higher $\mathrm{OH}$ stretching and stretching $\mathrm{CH}$ stretches, this can be caused by breaking the bond $\mathrm{C}=\mathrm{O}$ lignin at $1700 \mathrm{~cm}-1$ wave number at delignification treatment which causes more and more hemicellulose levels in the fiber. In the bleaching treatment fibers, the intensity of $\mathrm{O}-\mathrm{H}$ stretching and $\mathrm{C}-\mathrm{H}$ stretching becomes smaller. This shows that the removal of hemicellulose and lignin delignification treatment followed by bleaching treatment is more efficient than other treatments. 


\section{Characterization of Bark-Midrib Fibers using Chemical Treatment Variations as Reinforcement in Bark-Midrib Fiber Composites}

After all the testing is completed done, then do the analysis of the correlation of each test against the value of properties of mechanical composite fiber midrib bark. In the composite without treatment shows the results of the test pull with the value of the most lower when compared to treatment more are caused by group functions chemistry of lignin which still dominates the fiber midrib bark if compared with treatment more and based on results of tests FTIR, group function chemicals that are in the treatment of this form of group functions chemistry of cellulose that is $\mathrm{OH}, \mathrm{CH}$, and $\mathrm{CO}$ followed by the presence of several groups function chemical from lignin in the form of chemical functional groups $\mathrm{C}=\mathrm{O}, \mathrm{C}=\mathrm{C}$, and $\mathrm{C}=\mathrm{C}$ aromatic. Because this variable is a control variable and does not receive any treatment, the intensity of the $\mathrm{C}=\mathrm{O}$ functional group and the functional groups of other lignins in the bark midrib without treatment is still enormous.

The results of SEM images on the bark midrib fiber composite without treatment showed a failure in the form of debonding and an interfacial gap that occurred at the interface of the matrix with the filler. Failure is lowering the value of properties mechanic in the composite is significant. Judging from the structure, the fiber in a variable without treatment still has wall cells were intact and smooth indicated wall cell on the structure of the fiber still contains lignin and hemicellulose, which tend to decrease the value properties of mechanical composites.

Then, there are composites with treatment delignification that shows the results of the test pull with the value of the highest if compared treatment other. Value is reached on the treatment delignification with $\mathrm{NaOH}$ with a concentration of $5 \%$. Based on the results of tests FTIR, group function chemicals that are in the treatment of this form of group functions chemistry of cellulose that is $\mathrm{OH}, \mathrm{CH}$ and $\mathrm{CO}$ followed by the presence of several groups function chemistry of lignin in the form of group function of chemical $\mathrm{C}=\mathrm{C}$ and $\mathrm{C}=\mathrm{C}$ aromatic, also obtained hike intensity in $\mathrm{OH}$ functional groups and $\mathrm{CH}$ functional groups that show cellulose or hemicellulose structure.

Based on the results of SEM images on the bark midrib fiber composite delignification treatment showed a failure in the form of debonding and fiber pull-out. Failure debonding occurred in the area interface between matrix with filler. However, the existence of failures in the form of fiber pull-out indicates the interface that occurs between the matrix with filler has much better and more robust so that failure does not only occur in the area of the interface but also occurs in the area part in the structure of the fiber. This treatment also found a defect in the form of a micro void that can initiate a failure so that the value of mechanical properties decreases. In the structure of the fiber, the walls of the cell microfibrils have started degraded that indicates have reduced levels of lignin and hemicellulose that are on the walls of the cell. In the structure of the fiber also there is no lumen detected, making the fiber deformed from the structure a wall thereby increasing the density of the fiber.

And last, there composite with the treatment of bleaching shows the results of the test pull with the value of the highest when compared with the treatment of others. Value is reached on the treatment delignification by using $\mathrm{NaOH} \mathrm{5 \%}$, followed by treatment of bleaching using $\mathrm{H}_{2} \mathrm{O}_{2} 2 \%$ for 90 minutes. Based on the results of tests FTIR, chemical functional groups who are on treatment of this form of group functions chemistry of cellulose that is $\mathrm{OH}, \mathrm{CH}$ and $\mathrm{CO}$ followed by the presence of several groups function chemistry of lignin in the form of group function of chemical $\mathrm{C}=\mathrm{O}, \mathrm{C}=\mathrm{C}$, and $\mathrm{C}=$ $\mathrm{C}$ aromatic. From the results of the FTIR treatment, it was found that the intensity decrease in the $\mathrm{OH}$ and $\mathrm{CH}$ chemical functional groups. Removing hemicellulose and lignin can decrease the intensity of uptake in numbers wave around $3260-3280$ ( stalling $\mathrm{OH}$ ), 2900 ( overextend $\mathrm{CH}$ ), 1500 ( stretching $\mathrm{C}=\mathrm{C}$ ), and $1040 \mathrm{~cm}-1$ ( stretching CO) which show sump w a level of hemicellulose and lignin in the treatment is successfully reduced it significantly. However, because they are the group functions of $\mathrm{C}=\mathrm{O}, \mathrm{C}=\mathrm{C}$ and $\mathrm{C}=\mathrm{C}$ aromatic is a group function typical of lignin, can be said to be the removal of lignin has not happened is perfect.

The results of SEM images on the bark midrib fiber composite with bleaching treatment only showed failure in the form of fiber pull-out. It is indicated an interface between matrix with filler has been excellent, so the failure only occurred in parts of the fiber. Seen from the structure of the fiber, there is 
no cell wall between the microfibrils of the fiber, indicating that lignin and hemicellulose have been significantly reduced. The size of the fiber at the treatment is also much smaller than the treatment more due to the loss of lumen. When the lumen is lost, then the microfibril fiber will be deformed into a more flattened and huddle, thus reducing the number of voids contained in the fiber makes the fiber becomes denser.

\section{Conclusion}

The conclusion that can be obtained from the research that has been done is as follows:

1. Delignification treatment using $\mathrm{NaOH}$ to raise the mechanical properties of the composite fiber midrib bark. The mechanical properties value of the tensile test and the impact test I were at the highest value at $5 \% \mathrm{NaOH}$ concentration soaking time 3 hours with a tensile test value of $25.47 \mathrm{MPa}$ (increasing by $76.86 \%$ ) and an impact test value of $11.95 \mathrm{~kJ} / \mathrm{m}$ (increasing by $11,45 \%$ ).

2. Bleaching treatment using $\mathrm{H}_{2} \mathrm{O}_{2}$ increases the mechanical properties of the bark midrib fiber composite. The value of the mechanical properties of tensile test and impact test had the highest value at $\mathrm{H}_{2} \mathrm{O}_{2}$ concentration of $2 \%$ soaking time 90 minutes with a tensile test value of $35.09 \mathrm{MPa}$ (increased $39.36 \%$ ) and impact test value of $13.77 \mathrm{~kJ} / \mathrm{m}^{2}$ (increased by $15,22 \%$ ).

3. SEM image results carried out for each optimal treatment show that the composite without treatment has the interface between the matrix and the worst filler shown by the failure in the form of debonding and interfacial gap, followed by a composite delignification treatment where the interface between the matrix and the filler is better indicated by there is a failure in the form of debonding and fiber pull-out. In contrast, the bleaching treatment composite shows the best interface between the matrix and the filler because no failure was found in the interface area.

\section{Acknowledgement}

The final outcome of this paper required a lot of guidance and assistance from many people and we are grateful to have got this all along the completion of our assignment work.

\section{References}

Fadli, I., dkk. (2017) 'Pengaruh Fraksi Volume Serat Terhadap Kekuatan Mekanik Komposit rHDPE dengan Penguat Serat Pelepah Salak’, Skripsi. Surakarta : UNS.

Kementrian Pertanian RI. (2013) 'Komoditas Buah Salak di Indonesia’, Jakarta.

Laksono, A.D., Ismail, I. and Ningrum, C.R. (2019) 'Studi Pengaruh Komposisi Pengisi Serat Alam Kayu Galam (Melalueca Leucadendra) Bentuk Serutan pada Sifat Mekanik dan Mikrostruktur Komposit Poliester Sebagai Material Untuk Aplikasi Bilah Kincir Angin', JURNAL SAINTIS, 19(1), pp.9-14.

Laksono, A.D. and Adlina, N. (2019) 'Pengaruh Perlakuan Alkalinisasi Serat Alam Kayu Bangkirai (Shorea Laevifolia Endert) pada Sifat Mekanik Komposit dengan Matriks Poliester', JST (Jurnal Sains Terapan), 5(2), pp.60-66.

Raharji, W. P., dkk. (2016) 'Mechanical Properties of Untreated and Alkaline Treated Fibers from Zalacca Midrib Waste', s. USA : AIP. 